\title{
An overview of food safety and bacterial foodborne zoonoses in food production animals in the Caribbean region
}

\author{
Maria Manuela Mendes Guerra ${ }^{1}$ - Andre M. de Almeida ${ }^{1}$ - Arve Lee Willingham ${ }^{1}$
}

Received: 31 March 2016 / Accepted: 9 May 2016 / Published online: 23 May 2016

(C) The Author(s) 2016. This article is published with open access at Springerlink.com

\begin{abstract}
Foodborne diseases (FBDs) in the Caribbean have a high economic burden. Public health and tourism concerns rise along with the increasing number of cases and outbreaks registered over the last 20 years. Salmonella spp., Shigella spp., and Campylobacter spp. are the main bacteria associated with these incidents. In spite of undertaking limited surveillance on FBD in the region, records related to bacterial foodborne zoonoses in food-producing animals and their associated epidemiologic significance are poorly documented, giving rise to concerns about the importance of the livestock, food animal product sectors, and consumption patterns. In this review, we report the available published literature over the last 20 years on selected bacterial foodborne zoonoses in the Caribbean region and also address other food safety-related aspects (e.g., FBD food attribution, importance, surveillance), mainly aiming at recognizing data gaps and identifying possible research approaches in the animal health sector.
\end{abstract}

Keywords Caribbean region - Food animal products . Foodborne diseases · Livestock - Bacterial zoonosis · Surveillance

\section{Introduction}

Foodborne diseases (FBDs) are a serious global health problem. Microbial food safety is an increasing public health

Andre M. de Almeida

AdeAlmeida@rossvet.edu.kn

1 Ross University School of Veterinary Medicine, P.O. Box 334, Basseterre, St. Kitts and Nevis concern worldwide. Each year, as many as 600 million, or almost one in 10 people in the world, fall ill after consuming some sort of contaminated food. Of these, 420,000 people die, including 125,000 children under 5 years of age as stated in the World Health Organization's estimates on the global burden of foodborne diseases (WHO 2015). According to the CDC (2015), in the USA in 2013, 818 foodborne disease outbreaks were reported, resulting in 13,360 illnesses, 1062 hospitalizations, 16 deaths, and 14 food recalls. In the European Union (EU), in 2012, a total of 5363 foodborne outbreaks were reported, resulting in 55,453 human cases, 5118 hospitalizations, and 41 deaths (EFSA 2014). The most frequent causes of foodborne illness were diarrheal disease agents, particularly norovirus and Campylobacter spp. Foodborne diarrheal disease agents caused 230,000 (95\% UI 160,000-320,000) deaths, particularly non-typhoidal Salmonella enterica (NTS) which causes diarrheal and invasive disease (WHO 2015).

Even though these pathogens usually cause mild to moderate self-limiting gastroenteritis, invasive diseases and complications may occur, resulting in more severe cases. In the USA, the pathogen-food category pairs responsible for most outbreak-associated illnesses are Salmonella in chicken, Salmonella in pork, and Salmonella in seeded vegetables (CDC 2013). Evidence of FBD in low- and middle-income countries is still limited, but recent studies suggest that the most significant also comes from biological hazards (Grace 2015), with an estimated $20 \%$ of all human illness and death associated with endemic zoonoses (Grace et al. 2011). This is particularly true in Africa and the Middle East where few countries have surveillance programs. By contrast, all Central/South American and Caribbean countries have some forms of notification system. With respect to the Caribbean, the regional surveillance data in this region from 2005 to 2014 points to $\mathrm{FBD}$ as an increasing public health concern as 
reflected by the growing number of cases and outbreaks reported to the official agencies. Salmonella, Shigella, and Campylobacter prevail among bacterial causative agents and contribute to the overall annual economic costs of syndromic acute gastroenteritis (AGE) and FBD, with an estimated burden of \$US2.2 M and 40.4 M, respectively (Indar et al. 2015a, b). Considering animal health, the burden of animal and zoonotic infectious diseases in the Caribbean region is considered to be high. However, it is recognized that the majority of Caribbean countries lack the capacity to accurately recognize, diagnose, and respond to such diseases (ACP 2013). In spite of the surveillance system on FBD in the Caribbean region, records related to bacterial foodborne zoonoses in foodproducing animals and their associated epidemiologic significance are poorly documented. Aiming to assess the knowledge gaps in relation to this particular topic, and also to contribute to the identification of relevant areas where meaningful research may be conducted in the future, this overview covers (1) the evolution of food-producing animals in the region during the last two decades, (2) the main bacteria associated with FBD in the Caribbean, (3) food attribution with FBD in the Caribbean, (4) the importance of FBD to the Caribbean region and bacteria prevalence studies in food-producing animals and food products of animal origin in the Caribbean, (5) sources of animal and food contamination, and (6) the need for integrated animal-human surveillance of zoonotic foodborne pathogens.

\section{Material and methods}

A literature search was conducted on the available documentation published in English, Portuguese, and Spanish regarding bacterial foodborne zoonoses and food safety in the Caribbean Region from 1995 to 2015. Relevant studies were identified using a combination of key words in multiple databases, including PubMed, Science Direct, ISI Web of Science, and Google Scholar. The reference lists of relevant papers were searched for additional studies not found through database searching. We looked for studies on the most important foodborne bacterial hazards of current concern as considered by EDES c/o COLECAP (2012), Salmonella spp., Campylobacter spp., and verotoxigenic Escherichia coli. The combination was made of general terms related to bacterial studies and risk factors associated with food-producing animals (i.e., animal husbandry, farm animals, livestock, burden, meat, milk, eggs, public health, food safety, tourism) and each of the bacteria terms. Each search term was always used in combination with "Caribbean."

The countries of the Caribbean subregion, as defined for the purposes of this study, comprise the full member states of the Caribbean Community organization (Caricom), Antigua and Barbuda, the Bahamas, Barbados, Belize, Dominica, Grenada, Guyana, Haiti, Jamaica, Monserrat, Saint Kitts and
Nevis, Saint Lucia, Saint Vincent and the Grenadines, Trinidad and Tobago, and Suriname. Except for Belize, Guyana, and Suriname, these are all island states (Caricom Member States, Caricom 2015).

\section{Results and discussion}

\section{Food-producing animals and meat production in the Caribbean region}

In the Caribbean, livestock production varies in importance across the region depending on environment and culture. Production and consumption figures reflect subregionspecific livestock species and products. For example, Jamaica has the biggest livestock sector in the region, with well-developed poultry and other livestock industries (FAO 2007). Small ruminants, sheep and goats, are considered very important species in the Caribbean, not only for domestic meat production but also as a source of emergency income (Vokaty and Torres 1997). Among the livestock products produced in the region, meat has the highest production figures. However, the production of the Caribbean accounts for only $0.1 \%$ of total world meat production with these countries importing far more live animals and primary livestock products than they export (FAO 2007). This region is a net importer of meat, as local production is insufficient to meet demand, particularly that created by the tourist industry (Vokaty and Torres 1997). The overall populations of live animals of the major livestock species in the Caribbean in the years 1993 and 2013 are provided in Table 1 to show the evolution of livestock keeping during the past two decades. In the region, meat from poultry leads the industry, followed by pork and beef (FAOSTAT 2015). The amounts of food items produced from the major livestock species in the Caribbean for those same years are presented in Table 2 (FAO 2007).

The growth in livestock production in the last two decades reflects the regional trend of consumers increasingly moving away from the consumption of beef toward poultry, pork,

Table 1 Number of heads (average) of live animals of major livestock species in the Caribbean — comparison years 1993/2013

\begin{tabular}{lll}
\hline Livestock live animals & 1993 & 2013 \\
\hline Cattle & $9325 \mathrm{~K}$ & $9315 \mathrm{~K}$ \\
Goats & $2234 \mathrm{M}$ & $3508 \mathrm{M}$ \\
Pigs & $3877 \mathrm{~K}$ & $3542 \mathrm{~K}$ \\
Poultry & $1118 \mathrm{~K}$ & $2808 \mathrm{~K}$ \\
Sheep & $3777 \mathrm{M}$ & $2587 \mathrm{M}$ \\
\hline
\end{tabular}

Source: FAOSTAT 2015

$M$ million, $K$ thousand 
Table 2 Production of food items from the major livestock species in the Caribbean - comparison years 1993/2013

\begin{tabular}{lll}
\hline Livestock primary items & 1993 & 2013 \\
\hline Eggs-primary & $152,623 \mathrm{~K}$ & $253,085 \mathrm{~K}$ \\
Milk-cow & $14,588 \mathrm{~K}$ & $17,583 \mathrm{~K}$ \\
Milk-total & $16,182 \mathrm{~K}$ & $19,753 \mathrm{~K}$ \\
Meat-beef & $224,889 \mathrm{~K}$ & $238,226 \mathrm{~K}$ \\
Meat-chicken & $336,066 \mathrm{~K}$ & $569,219 \mathrm{~K}$ \\
Meat-goat & $7,385 \mathrm{~K}$ & $11,802 \mathrm{~K}$ \\
Meat-pork & $214,999 \mathrm{~K}$ & $339,985 \mathrm{~K}$ \\
Meat-sheep & $7,372 \mathrm{~K}$ & $13,034 \mathrm{~K}$ \\
Meat-total & $801,1 \mathrm{~K}$ & $1,184,3 \mathrm{~K}$ \\
\hline
\end{tabular}

Source: FAOSTAT 2015

$K$ thousand

eggs, and dairy products (FAO 2014), which is in line with global consumption trends. The exception is the consumption of mutton and goat that still prevails and continues to grow in the region, and which is mostly consumed by the local population rather than by visiting tourists. Generally, there is a preference for goat meat rather than mutton by Caribbean nationals (Vokaty and Torres 1997). Most likely, the consumption of meat and food animal products in the region will follow global projections for 2050 of a moderate increase in meat consumption, based mainly on increased consumption of pork and especially poultry, while the consumption of eggs and milk are expected to continue to increase and decrease, respectively (at least in developed countries) (Kearny 2010).

\section{Bacteria associated with FBD in the Caribbean}

Pathogens associated with the majority of outbreaks in the USA and Europe also rank among the most common causes of outbreaks and FBD cases in the Caribbean, namely, those associated with AGE and diarrhea as seen in a set of studies aimed at estimating the burden of illness (BOI) in seven Caribbean countries (i.e., Trinidad and Tobago, Dominica, Guyana, St Lucia, Grenada, Barbados, Jamaica) from 2008 to 2013. Salmonella spp. and Shigella spp. were the most frequently found and with the highest estimated burdens after norovirus (Indar et al. 2015b). In Trinidad and Tobago in 2008 and 2009, Lakhan et al. (2013) related Salmonella and Shigella, along with rotavirus and norovirus, to AGE. In Dominica (Ahmed et al. 2013), Salmonella and Shigella were also related to AGE, with norovirus and Giardia as the leading etiologic agents. Giardia was also reported to be the prevalent etiologic agent in Guyana; however, no data was reported regarding bacterial agents due to a lack of laboratory capacity (Persuad et al. 2013). In St. Lucia and Grenada (Gabriel et al. 2013; Glasgow et al. 2013), Salmonella was the most commonly isolated enteropathogen associated to AGE, followed by rotavirus and norovirus, respectively. In Barbados, norovirus led the foodborne pathogens causing AGE-related illness, followed by Salmonella and Campylobacter. In Jamaica, the burden of illness study revealed that there was no determination of pathogen specific causes of AGE (Fletcher et al. 2013). Overall, underreporting of syndromic AGE in these countries ranged from 64 to $83 \%$ and for laboratory-confirmed FBD pathogens from 74 to $99 \%$ (Indar et al. 2015b).

In addition to these retrospective, cross-sectional studies, other reports on the frequency of enteropathogens in human fecal and rectal specimens indicate Shigella, Salmonella, and enteropathogenic $E$. coli as the most frequently found pathogens in Trinidad (Khan-Mohammed et al. 2005) and Salmonella, Campylobacter, and Shigella in Barbados (Kumar et al. 2014). Furthermore, the Caribbean Public Health Agency (CARPHA) has recently compiled data regarding FBD and Salmonella infections in 21 Englishspeaking Caribbean countries detected through regional surveillance in the years 2005-2014 (Indar et al. 2015a). During this period, the number of cases of reported human FBD in the Caribbean increased by $26 \%$. Non-typhoidal Salmonella was the most common pathogen causing FBD (47\%), followed by ciguatera poisoning (24\%), Salmonella typhi (9.8\%), Shigella (8\%), Campylobacter (6\%), and norovirus $(3.9 \%)$. There was an increase in non-typhoidal Salmonella (51\%), norovirus (26\%), and Campylobacter (25\%) from 2005 to 2014, while Salmonella typhi (-99\%), Shigella $(-54 \%)$, and ciguatera $(-18 \%)$ decreased during the same time period. Salmonella and Shigella were reported from more than half of the countries. Campylobacter and ciguatera were reported from three to six countries and norovirus from five to seven countries. A wider range of pathogens were reported from 2010 onward. Salmonella serotyping data indicated that while 146 serotypes were identified, enteritidis (29\%) and typhimurium $(21 \%)$ were the two most prevalent serotypes isolated from 2005 to 2014, followed by Mississippi (4.9\%). Enteritidis was the most commonly isolated in Trinidad and Tobago, Jamaica, and Suriname. Typhimurium was dominant in Barbados and Mississippi in Bermuda (Indar et al. 2015a).

\section{Food attribution with FBD in the Caribbean}

Specific attribution studies in the Caribbean region are scarce. Indar-Harrinauth et al. (2001) published a case control study which provided evidence for the linkage of consumption of eggs with Salmonella enteritidis infection in Trinidad and Tobago. In the recently published WHO's estimates of the global burden of foodborne diseases (2015), the expert elicitation results regarding sub-regional attribution estimates of the proportion of illnesses caused by Campylobacter spp., non-typhoidal Salmonella spp., and Shiga toxin-producing 
E. coli (STEC), through each exposure pathway in the Caribbean region, are undoubtedly related to food sources. Campylobacter illness is mainly associated with food sources $(0.68 \%)$ followed by contact with animals (domestic and wild; $0.11 \%$ ); non-typhoidal Salmonella enterica food source $(0.49 \%)$, animal contact $(0.19 \%)$, and human to human contact $(0.15 \%)$; and Shiga toxin-producing $E$. coli $0.53 \%$ related to food sources, $0.17 \%$ to direct contact with animals (domestic and wild), and $0.11 \%$ related to human to human contact. Previously, in an attempt to overcome the deficiency of data, Pires et al. (2011) estimated the contribution of different food sources to human diseases using outbreak data available from Latin America and the Caribbean region between 1993 and 2010. Authors reviewed 6313 bacterial outbreaks reported by 20 countries and concluded that in general, the most important sources of bacterial disease were meat and dairy products, water, and vegetables in the 1990s, whereas eggs, vegetables, grains, and beans were the most important sources in the 2000s. The most frequently reported pathogens were Staphylococcus aureus, Salmonella spp., E. coli, and Clostridium perfringens in the 1990s, while Salmonella spp., Vibrio parahemolyticus, and Shigella spp. were the most frequently reported in the 2000s. The associated fluctuations observed for each pathogen between decades and countries were linked to changes in the control of zoonotic diseases, changes in food consumption habits, changes in public health focus, and changes in availability of data regarding different pathogens. The authors also identified many data gaps in the region and noted that some of the data does not represent the region totally but only some of the countries, considering the great variability in terms of reporting, namely, of the most frequently described pathogens. For example, FBD outbreak data from only two of the Caribbean countries, Bahamas and Barbados, were considered in the present overview; thus, the data can only be seen as an indicator of the reality in the Caribbean, based on geographical, cultural, and food consumption similarities.

\section{The importance of FBD in the Caribbean region}

Apart from the substantial economic burden on the population and health care system imposed by FBD, the associated economic impact for nations that depend on tourism for financial support is also a reason of concern. Tourism is very important to the Caribbean economies, contributing about a third of the regional GDP. The region regularly and, in recent years, increasingly receives large numbers of passengers from cruise ships and also large numbers of visitors staying in hotels and resorts many of them with all inclusive meal plans. During the first 6 months of 2015, the Caribbean experienced a $7 \%$ increase in visitors, which was considered to be the highest increase of any region in the world. This comes even after the region attracted a record setting 26.3 million tourists in
2014 (CTO 2015). The tourism industry is known to be vulnerable to health, safety, security, and environmental challenges, and therefore, FBD may impact negatively on the image and sustainability of this industry with potential visitors becoming reluctant to travel to regions where there is a known or perceived risk of becoming infected with FBD (Paredes et al. 2000; Ehrenberg and Ault 2005; Indar 2015). In the Caribbean, FBD outbreaks are frequently registered by the health authorities and many are known to involve tourists and to be associated with high economic losses to the tourism operators (Indar 2015). Additionally, there are some studies concerning the epidemiology of travel-related pathogens indicating that traveling to the Caribbean region (and also to other regions of the world) may represent a high risk for acquiring foodborne pathogens, Campylobacter, Salmonella, and Shigella in US travelers to the Caribbean (Kendall et al. 2012); Salmonella enteritidis in Ontario, Canada, travelers (Tighe et al. 2012); and Campylobacter in Dutch travelers (Mughini-Grass et al. 2014). More recently, the prevalence of Shiga toxin-producing Shigella species isolated from French travelers returning from the Caribbean was assessed (Gray et al. 2015), providing evidence of the emergence of Shiga toxin-producing Shigella on the island of Hispaniola (Haiti and Dominican Republic). This study demonstrates that travelers are capable of spreading these particular Shigella strains globally, expanding the risk to a broader level. This is a finding that can be extrapolated to other travel-related pathogens.

\section{Bacteria prevalence studies in food-producing animals and food products of animal origin in the Caribbean}

\section{Salmonella spp.}

The prevalence of Salmonella spp. in food-producing animals and food products of animal origin in the Caribbean was reported in 14 studies published between 1995 and 2015 . Twelve of these studies were conducted in Trinidad, one in Barbados and one in Trinidad, Grenada, and St. Lucia simultaneously. As seen in Table 3, two studies concerned livestock and poultry, one concerned milk and one concerned raw poultry; five studies concerned layer farms and eggs; and finally, six studies concerned ready-to-eat meats. Prevalence of this bacteria in fecal samples of live animals (livestock and ducks) was low, with values of $2.3-2.7 \%$ in livestock (Adesiyun et al. 2001) and $4.55 \%$ in ducks (Rampersad et al. 2008). In layer farms and eggs, two studies indicated prevalences ranging from 3.8 to $4.66 \%$ on egg shells and $1.2-7.6 \%$ in egg contents (Indar et al. 1998; Adesiyun et al. 2005); 40-73\% of layer farms were positive for Salmonella which was revealed in three other studies (Aimey et al. 2013; Adesiyun et al. $2014 a, b)$. The only study conducted on milk detected Salmonella in $1.7 \%$ of the samples (Adesiyun et al. 1996), 


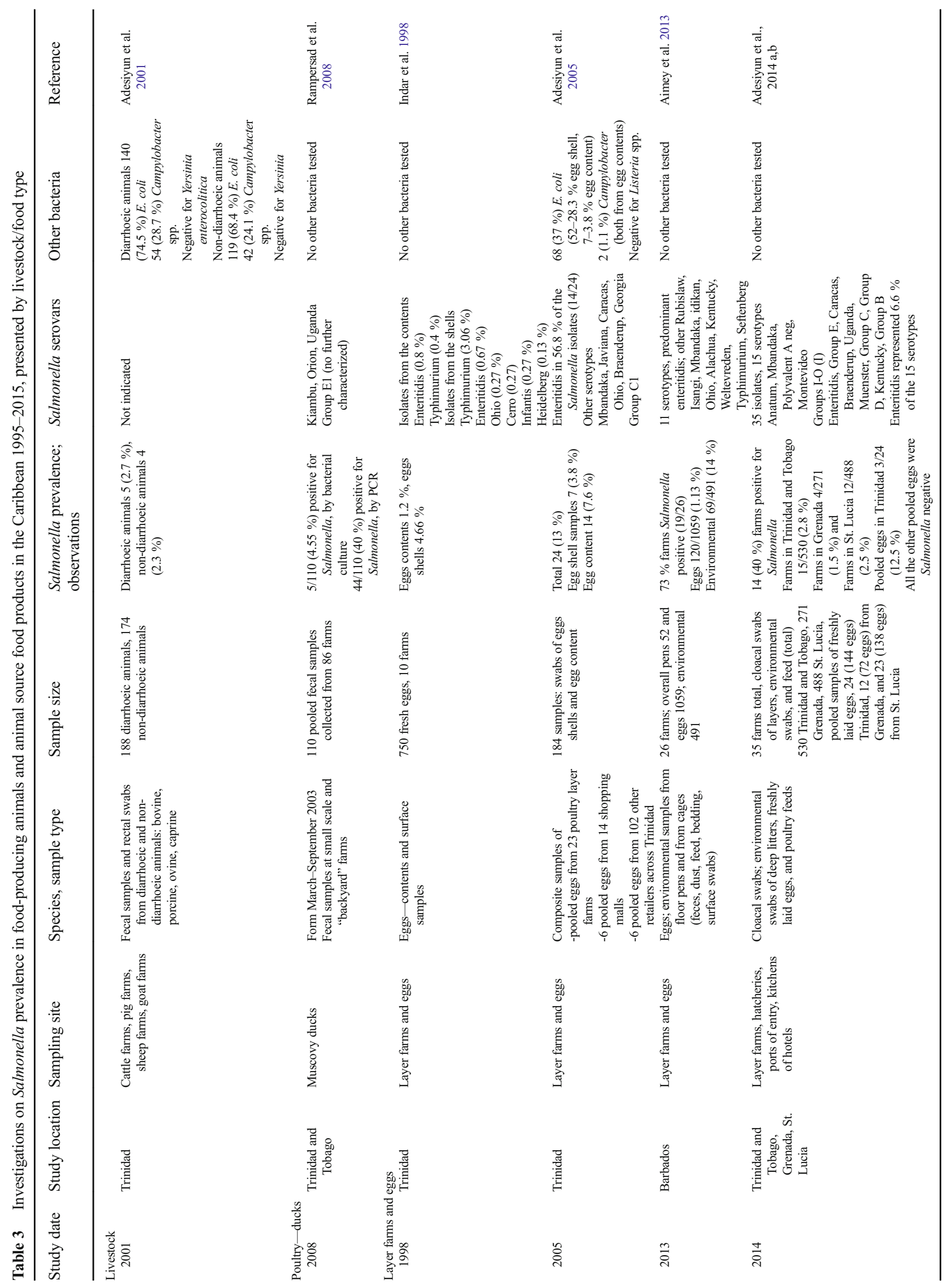




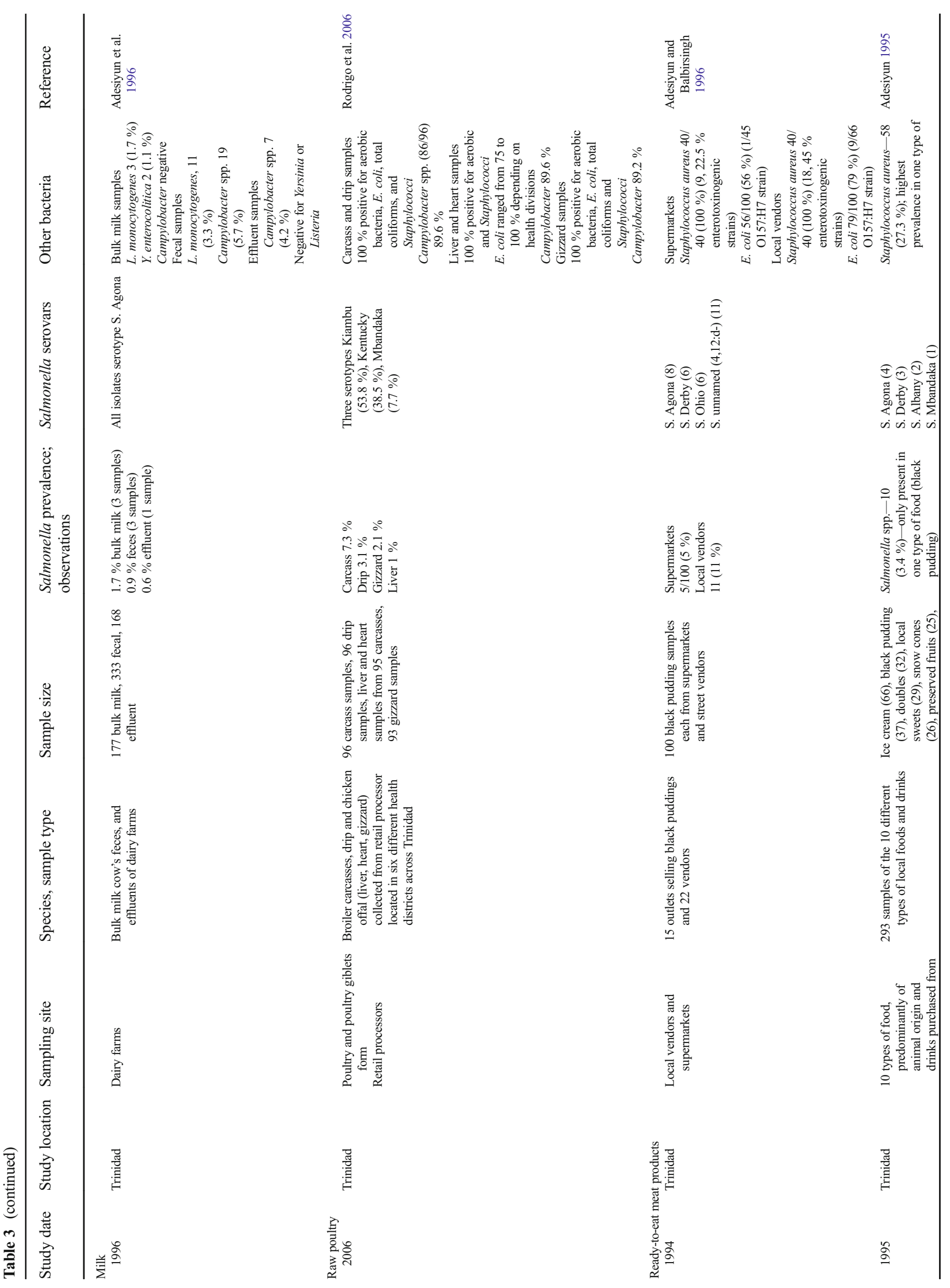




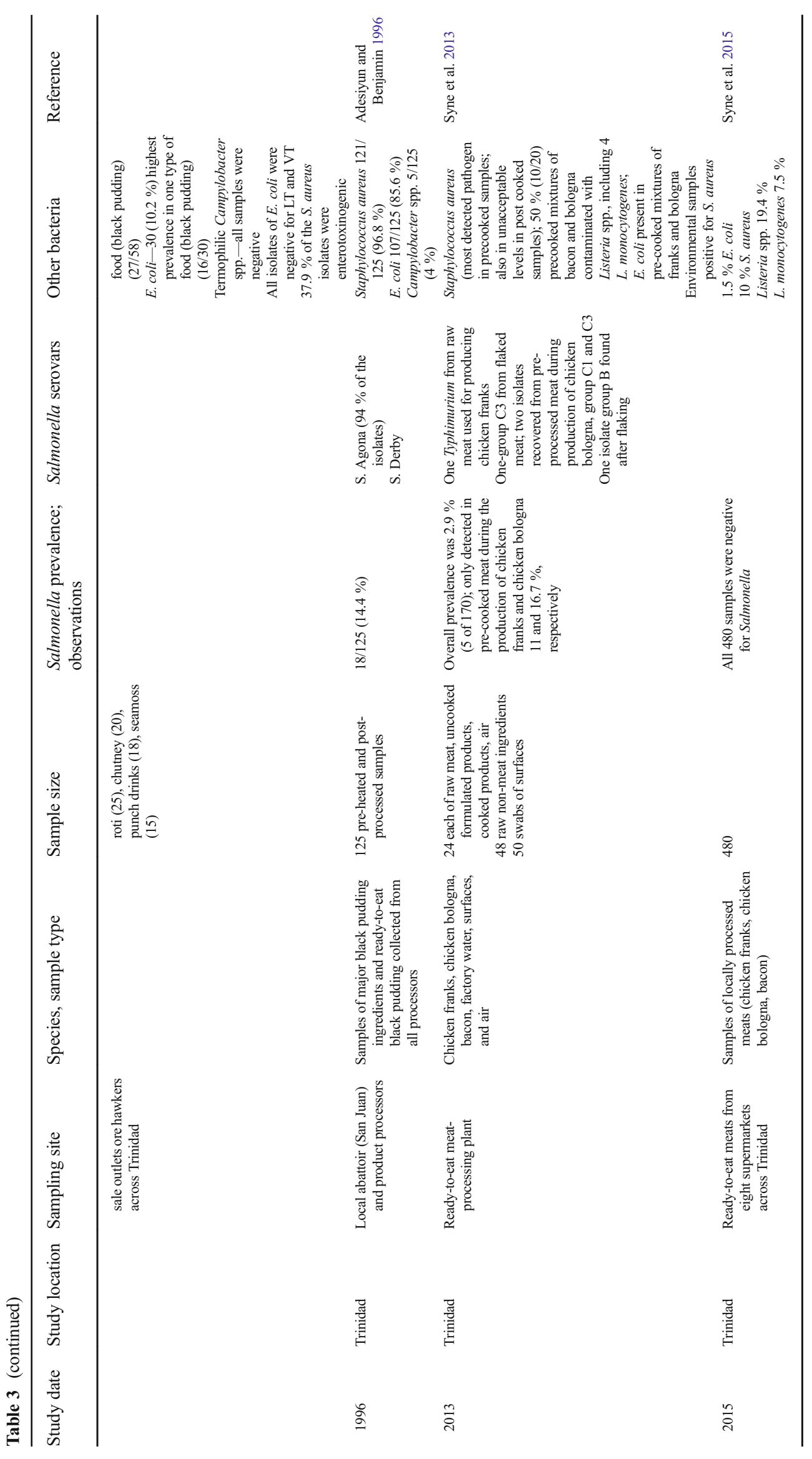


while in raw poultry, Salmonella was present in $7.3 \%$ of the carcasses (Rodrigo et al. 2006). In ready-to-eat meat products, Salmonella was present in black pudding varying from 3.4 to $14.4 \%$ in the three studies conducted on this food type (Adesiyun and Balbirsingh 1996; Adesiyun 1995; Adesiyun and Benjamin 1996). In ready-to-eat meat-processing plants, Salmonella was detected only in pre-cooked meat in one of the studies (Syne et al. 2013), and in a more recent study focused on ready-to-eat meat available in supermarkets, Salmonella was not detected in a total of 480 samples (Syne et al. 2015). Although serovar or molecular data are limited, apparently, there is a predominance of Salmonella enteritidis in samples from layer farms and eggs, while in ready-to-eat meat products, Salmonella agona and Salmonella derby are the predominant serovars (Table 3). Although Salmonella enteritidis showed predominance in the human isolates in Trinidad and Tobago (Indar et al. 2015a) and in eggs sampled for the studies conducted in the same country (Adesiyun et al. 2005), there are no studies providing information on the issue of serovars. Data from the PulseNet Latin America and Caribbean Network (Campos et al. 2012) showed a high genetic diversity among the strains of Salmonella typhimurium, Salmonella enteritidis, and Salmonella typhi (ST) human isolates circulating in six countries of the region.

\section{Campylobacter spp.}

Publications on the prevalence of Campylobacter spp. refer to studies conducted in Trinidad, Barbados, and Grenada. Only four studies were aimed at specifically isolating Campylobacter in livestock and food products of animal origin (Table 4), while there are other studies that reveal the presence of Campylobacter together with other pathogenic bacteria as seen in Table 3 and also in Table 4. Overall, the prevalence of Campylobacter is high in poultry, with values of about $90 \%$ for the analyzed samples, carcass $89.6 \%$, liver and heart $89.6 \%$, gizzard $89.2 \%$ (Rodrigo et al. 2006), cloacal swabs $94.2 \%$ (Workman et al. 2005), and ceca $72 \%$ (Miller et al. 2009)-93.5\% (Hariharan et al. 2009). For chicken layers, two studies indicated prevalences of $22 \%$ (Miller et al. 2009) and 56.3\% (Hariharan et al. 2009). Prevalence in pigs varied from $20 \%$ in carcass swabs to $54 \%$ in rectal swabs (Adesiyun and Krishnan 1995) and 11.8\% (Gibbons et al. 2006) to $90.5 \%$ (Workman et al. 2005) in feces. A study conducted in feces and rectal swabs from cattle, pigs, sheep, and goats indicated the overall prevalence of Campylobacter to be $28.7 \%$ in diarrheic animals and $24.1 \%$ in non-diarrheic animals (Adesiyun et al. 2001). Low-prevalence figures were detected in sheep feces (4.2\%) (Workman et al. 2005), goat rectal swabs (3.7\%) (Stone et al. 2014), and dairy cattle feces (ranging from 0 to $5.7 \%$ ) (Workman et al. 2005; Adesiyun et al. 1996, respectively). Regarding meat, Workman et al. (2005) recovered Campylobacter from the following: chicken
$58.4 \%$, pork $3.9 \%$, beef $1.8 \%$, and turkey $5 \%$. In ready-toeat meat products, Campylobacter was found in black pudding (4\%; Adesiyun and Benjamin 1996) and together with other pathogens in processed ready-to-eat meat products in a meat-processing plant associated with a recall of the following three processed meat products: chicken franks, ready-to-eat spice ham, and turkey ham (Gibbons et al. 2006). Studies also indicate a general higher frequency of Campylobacter coli than Campylobacter jejuni. Detailed information is given in Tables 3 and 4. Regarding the epidemiology of $C$. jejuni and C. coli, there is a reference on the typing of these two isolates, but this study was mainly intended to assess the benefits and limitations of different typing approaches, rather than an epidemiological study (Behringer et al. 2011). Previous to this, Workman et al. (2005) investigated the sources of this bacteria in a poultry production and packing operation in Barbados finding 10 distinct RAPD genotypes and no evidence of vertical transmission of Campylobacter in the flock, suggesting that it might have been contaminated from more than one source in the farm environment under investigation. Also, Miller et al. (2009) performed DNA identification of C. jejuni and C. coli from poultry in Grenada using combined typing methods, finding phylogenetic associations with previously described poultry-related strains.

\section{Verotoxigenic E. coli and other pathogenic zoonotic bacteria}

The presence of $E$. coli and also of other pathogenic zoonotic bacteria in livestock and food products of animal origin in the Caribbean region is shown in some of the previous mentioned studies, where apart from Salmonella spp. and/or Campylobacter spp., the authors broadened their research to other pathogenic bacteria (Tables 3 and 4).

Addressing the presence of $E$. coli, there was one study aimed at specifically determining the presence of verocytotoxigenic $E$. coli (VTEC) in dairy farms in Trinidad-E. coli was isolated from all analyzed sources (fecal samples collected from milking cows, calves, and humans; rectal swabs obtained from pet farm dogs; and bulk milk as well as effluent samples from the milking parlor) with 61 isolates found positive for VTEC, $16.6 \%$ from cows, $14.6 \%$ from calves, $3.2 \%$ from farm dogs, and $7.1 \%$ from humans (Roopnarine et al. 2007). Another study also conducted in Trinidad (Table 3 ) indicated the presence of this microorganism in livestock with a 74.5 and $68.4 \%$ occurrence in diarrhoeic and non-diarrhoeic animals, respectively (Adesiyun et al. 2001). In the same country, verotoxigenic E. coli was detected in $37 \%$ of tested eggs (Adesiyun et al. 2005 ) and in $75-100 \%$ of raw poultry samples. Investigations of ready-to-eat meat products in Trinidad indicated E. coli levels of $1.5 \%$ (Syne et al. 2015), 10.2\% (Adesiyun 1995), $34 \%$ (Gibbons et al. 2006), 56-79\% (Adesiyun and Balbirsingh 1996), and 85.6\% (Adesiyun and Benjamin 


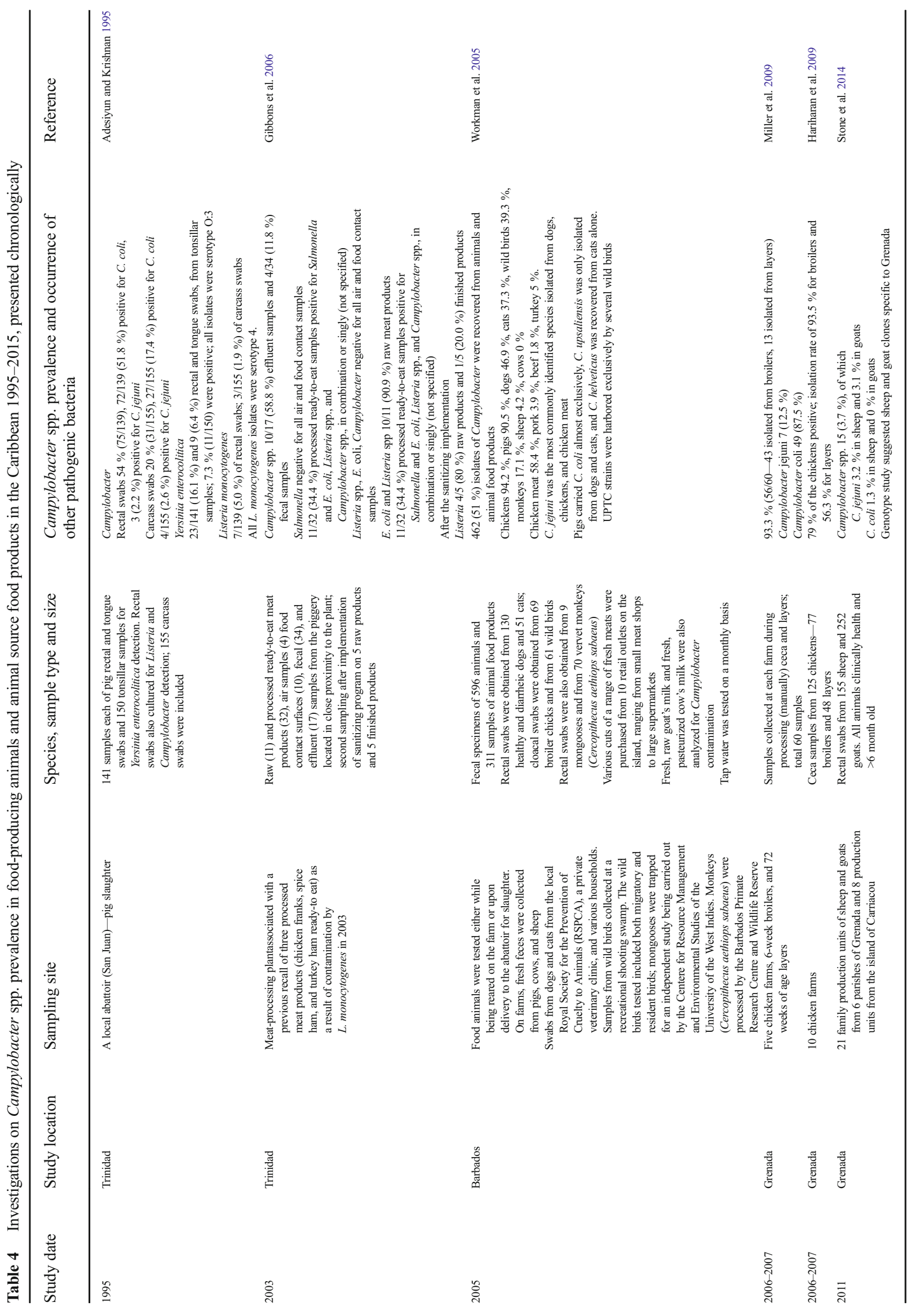


1996). Very few of these studies tested E. coli for VTEC (Table 3).

Other bacteria that are mentioned in the searched literature include Listeria spp., Yersinia spp., and S. aureus. In pig samples at slaughter, Listeria monocytogenes was found in $5 \%$ of the rectal swabs and $1.9 \%$ of the carcass swabs and Yersinia enterocolitica in 16.1 and $6.4 \%$ of the rectal and tongue swabs, respectively, and from $7.3 \%$ of the tonsillar samples (Adesiyun and Krishnan 1995). These two bacteria were also detected in bulk milk samples, 1.7 and $1.1 \%$, respectively, and L. monocytogenes was found in fecal samples of cows in the same study (Adesiyun et al. 1996). Listeria spp. is referred to in studies conducted in ready-to-eat meat products, with levels of $18.3 \%$ (Syne et al. 2013) and 19.4\% (Syne et al. 2015). Finally, regarding $S$. aureus prevalence, it has been found in milk or milk-related environments in Trinidad, $100 \%$ of the 287 milk samples (Adesiyun et al. 1995), raw poultry with all carcass (96), drip (96), liver and heart (95), and gizzard (93) samples positive for this bacteria (Rodrigo et al. 2006). Regarding ready-to-eat meat products, S. aureus was present in $100 \%$ of the 80 black pudding samples acquired in 1994 in both supermarkets and street vendors in Trinidad (Adesiyun and Balbirsingh 1996) and in $27.3 \%$ of the 293 ready-to-eat samples, including black pudding collected 1 year later in the same country (Adesiyun 1995), with a higher presence in the black pudding samples (27/58) and again later in $96.8 \%$ of the 125 black pudding samples also (Adesiyun and Benjamin 1996). Two additional studies conducted in Trinidad in 2013 and 2015 reveal the presence of S. aureus, $27.1 \%(46 / 170)$ in samples of air, food, and environment of a large meat-processing plant, being present in both pre-cooked and post-cooked meat samples, and in $10 \%$ of the 480 ready-to-eat samples collected at different supermarkets (Syne et al. 2013, 2015) (Table 3). Enterotoxinogenic strains were determined in only two of the above mentioned studies, with 33.8 and $37.9 \%$ positive out of the isolated strains (Adesiyun 1995; Adesiyun and Balbirsingh 1996).

Overall, bacteria prevalence studies in food-producing animals and food products of animal origin mentioned in this review have limited significance. During the past 20 years, only a few sporadic studies were published, mostly related to investigations on layer farms and eggs and ready-to-eat meat products conducted in only three of the Caribbean countries (Trinidad, Barbados, Grenada), which makes it difficult to determine regional trends. Another limitation relates to the diverse sampling plans and methodological steps followed in the detection and identification of the microorganisms in these studies, which make it difficult to compare and interpret the findings.

\section{Sources of animal and food contamination}

Many foods of both animal and plant origin can be contaminated by disease-producing microorganisms at one or more stages of food production, beginning on the farm and ending in the home. While livestock and other domestic animal sources are often implicated, the ultimate sources of contaminants can extend back to infected feral or wild animals (Adesiyun et al. 1998; Hulebak et al. 2013). Several wildlife species living in the Caribbean are recognized as carriers and shedders of the pathogens addressed in this overview. Roach et al. (2003) found Salmonella and Shigella in captive African green monkeys (Chlorocebus aethiops) in Barbados with 16 and 32 of 1608 monkeys found positive for Salmonella spp. and Shigella sonnei, respectively. In St. Kitts and Nevis, an outbreak of Yersinia enterocolitica was registered in captive green monkeys (Soto et al. 2013). Mongoose-small Asian mongoose (Herpestes javanicus) and small Indian mongoose (Herpestes auropunctatus) _ are recognized as carriers and shedders of Salmonella spp. as seen in Grenada (Miller et al. 2014, 2015) and thermophilic Campylobacter spp. as observed in Barbados (Rhynd et al. 2014). Wild rats (Rattus spp.) have also been shown to be carriers of Salmonella spp., Campylobacter spp., and E. coli (Nkogwe et al. 2011). Other animals species found in the Caribbean and seen as carriers of FBD that include the blue land crab (Cardisoma guanhumi), commonly used as a food item in the Caribbean region that has been shown to harbor E. coli and Salmonella (Amadi et al. 2015) and wild and domestic green iguanas (Iguana iguana) used as food for example in Grenada, may serve as a reservoir of Salmonella (Sylvester et al. 2013). Finally, cane toads (Bufo marinus) were found with high levels of Salmonella and harboring serovars that are emerging as causes of human disease in the western hemisphere (Drake et al. 2013). In spite of this compilation of possible wild animal contamination sources, no study was found attempting to correlate rates of infection in wild animals and livestock animals in the region. Only a small number of studies were found correlating rates of infection in live animals and food contamination (Adesiyun et al. 2014a, b), and only a few others provide specific data on food attribution with FBD in the Caribbean as previously mentioned.

\section{The need for integrated animal-human surveillance of zoonotic foodborne pathogens}

It is recognized that in order to assure the safety of food of animal origin, zoonotic pathogens in foods have to be controlled through a continuous farm to fork system, which should take into account not only the assessment of risks but also technical possibilities, consumers' attitude/behaviors, and cost-benefit analysis (Nastasijević 2000). Several studies recognize the need for effective surveillance systems to identify sources of disease (Nastasijević 2000; Pires et al. 2011) and the integration of 
animal health, food pathogen, and foodborne disease surveillance globally and especially in developing and in-transition countries (de Balogh et al. 2013; Vidal et al. 2013) and specifically in the Americas and the Caribbean region (PercedoAbreu et al. 2011; Hulebak et al. 2013; Gebreyes et al. 2014). Effective surveillance of animal diseases is in fact a priority for the World Organization of Animal Health (OIE) and Food and Agriculture Organization of the United Nations (FAO) (Corning 2014), and tools are available nowadays to prioritize zoonoses using a One Health perspective in a way to minimize fiscal and personal limitations as well as the absence of comprehensive prevalence data. These can be used by human and animal health agencies to coordinate across sectors in a more effective response to zoonotic diseases (Rist et al. 2014).

In the Caribbean, interactions between medical, wildlife, and veterinary professionals are currently considered very limited. The low internal capacity of Caribbean governments, their limited resources, and the high burden of infectious human and animal disease across the Caribbean region are recognized and point toward the relevance of pursuing a holistic One Health approach, with interdisciplinary engagement on a regional scale (ACP 2013). To overcome these limitations, national and regional organizations such as the Caribbean Animal Health Network (CaribVET) are increasingly committed to implementing or improving established surveillance systems according to a One Health approach. Results from a survey conducted by CaribVET in 2009 "Prevention of contamination of the human food chain" was identified as the most important area for the application of risk assessment methodologies to select animal health issues (Percedo Abreu 2011). This result was correlated with the influence of environmental characteristics of the Caribbean tropical area and the growing importance of tourism in the islands. Regarding this last aspect, response surveillance systems are also identified and under preparation for hotels and cruise ships to address health, safety, and environmental issues that pose serious threats to the sustainability of tourism in the region (Indar 2015). There are also environmental health initiatives with the Caribbean EcoHealth Program (CEHP) being carried out to enhance integrated research and capacity development (Forde et al. 2011).

Contributing to an overall human-animal health surveillance strategy, starting at a regional level and in an animal health research perspective, several approaches could be undertaken by each country to gather relevant information to be used in targeting actions in order to improve food safety. Addressing food of animal origin under a farm to the fork approach research strategy, we suggest data collection on the following points (an initial prioritization of zoonoses could be considered):

- Systematic examination of potential hazards that exist in each stage of the meat and other food animal products (milk, eggs) chain and to determine their epidemiological significance;
- Evaluate and manage hygiene and sanitary control systems on farms and at food processing sites;

- Determine sources of animal and food contamination, including wildlife;

- Explore food safety practices and perceptions of consumers.

The outcomes of these research studies could then be used to develop interventions aimed at protecting food animals from infections and reduce dissemination of foodborne hazards.

\section{Conclusions}

Livestock is very important economic and cultural sectors in the Caribbean. Future projections indicate changes in the dietary habits of local populations, a considerable increase in meat consumption and rising demand for other animal products such as eggs. Presently, studies limited to a few countries in the Caribbean indicate an apparent high prevalence of Campylobacter and E. coli in eggs and chicken and a low prevalence of Salmonella spp. in food-producing animals and food products of animal origin. Further research is needed to identify which animals and foodstuffs are the main sources of infections. FBDs are a substantial concern in the region, and Salmonella spp., Shigella spp., and Campylobacter spp. are the main causative bacteria of these incidences, with Salmonella showing a rise in reported human cases over the past 20 years. Therefore, further epidemiological studies are needed to establish possible correlations between human and animal diseases that could lead to the establishment of preventive measures. These will ultimately benefit not only the health of populations but would also contribute to increasing tourists' confidence in visiting the Caribbean region. From the animal health regional perspective, further research measures could contribute with relevant data to establish or improve existent integrated surveillance systems to assure the safety of food of animal origin.

\section{Compliance with ethical standards}

Conflict of interest The authors declare that they have no conflict of interest.

Ethical approval The manuscript does not contain clinical studies or patient data.

Open Access This article is distributed under the terms of the Creative Commons Attribution 4.0 International License (http:// creativecommons.org/licenses/by/4.0/), which permits unrestricted use, distribution, and reproduction in any medium, provided you give appropriate credit to the original author(s) and the source, provide a link to the Creative Commons license, and indicate if changes were made. 


\section{References}

ACP, 2013. ACP science and technology program. http://www.acp-st.eu/ sites/all/files/projects-factsheet/ACP-330-215_PRINT.pdf

Adesiyun, A.A. 1995. Bacteriologic quality of some Trinidadian readyto-consume foods and drinks and possible health risks to consumers, Journal of Food Protection, 58(6):651-655

Adesiyun, A.A. and Balbirsingh, V. 1996. Microbiological analysis of "black pudding", a Trinidadian delicacy and health risk to consumers, International Journal of Food Microbiology, 31:283-299

Adesiyun, A.A. and Benjamin, L.A. 1996. Identification of microbial hazards, methods for their control and critical control points for black pudding ("boudin noir"), Food Microbiology, 13: 243-256

Adesiyun, A.A. and Krishnan, C. 1995. Occurrence of Yersinia enterocolitica O:3, Listeria monocytogenes O:4 and thermophilic Campylobacter spp. in slaughter pigs and carcasses in Trinidad, Food Microbiology, 12: 99-107

Adesiyun, A.A., Webb, L. and Rahaman, S. 1995. Microbiological quality of raw cow's milk at collection centers in Trinidad, Journal of Food Protection, 58(2):139-146

Adesiyun, A.A., Webb, L.A. and Kaminjolo, J.S. 1996. Prevalence of Salmonella, Listeria monocytogenes, Campylobacter spp., Yersinia enterocolitica and Cryptosporidium spp. in bulk milk, cows' faeces and effluents of dairy farms in Trinidad, Revue d Elevage et de Medecine Veterinaire des Pays Tropicaux, 49(4):303-9

Adesiyun, A.A., Seepersadsingh, N., Inder, L. and Caesar, K. 1998. Some bacterial enteropathogens in wildlife and racing pigeons from Trinidad, Journal of Wildlife Diseases, 34(1):73-80

Adesiyun, A.A., Kaminjolo, J.S., Ngeleka, M., Mutani, A., Borde, G., Harewood, W. and Harper, W. 2001. A longitudinal study on enteropathogenic infections of livestock in Trinidad, Revista da Sociedade Brasileira de Medicina Tropical, 34(1):29-35

Adesiyun, A., Offiah, N., Seepersadsingh, N., Rodrigo, S., Lashley, V., Musai, L. and Georges, K. 2005. Microbial health risk posed by table eggs in Trinidad, Epidemiology and Infection, 133:1049-1056

Adesiyun, A., Webb, L., Musai, L., Louison, B., Joseph, G., StewartJohnson, A., Samlal, S. and Rodrigo, S. 2014a. Survey of Salmonella contamination in chicken layer farms in three Caribbean countries, Journal of Food Protection, 77(9):1471-80

Adesiyun, A., Webb, L., Musai, L., Louison, B., Joseph, G., StewartJohnson, A., Samlal, S. and Rodrigo, S. 2014b. Resistance to antimicrobial agents among Salmonella isolates recovered from layer farms and eggs in the Caribbean region, Journal of Food Protection, 77(12):2153-2160

Ahmed, S., Ricketts, P., Bergeron, M., Jones, W. and Indar, L. 2013. Distribution, burden, and impact of acute gastroenteritis in Dominica, 2009-2010, Journal of Health, Population and Nutrition 31(4 suppl 1):43-56

Aimey, V., Hunte, K., Whitehall, P., Sanford, B., Trotman, M., Delgado, A., Lefrancois, T., Shaw, J. and Hernandez, J. 2013. Prevalence of and examination of exposure factors for Salmonella on commercial egg-laying farms in Barbados, Preventive Veterinary Medicine, 110: 489-496

Amadi, V.A., Peterson, R., Matthew-Belmar, V., Sharma, R. and Hariharan, H. 2015. Prevalence and antibiotic susceptibility of gram-negative aerobic bacteria cultures form the intestine and hepatopancreas of blue land crab (Cardisoma guanhumi) in Grenada, West Indies, British Microbiology Research Journal, 5(2):169-179

Behringer, M., Miller, W.G. and Oyarzabal, O.A. 2011. Typing of Campylobacter jejuni and Campylobacter coli isolated from live broilers and retail broiler meat by flaA-RFLP, MLST, PFGE and REP-PCR, Journal of Microbiological Methods, (8492):194-201

Campos, J., Pichel, M., Vaz, T.M.I., Tavechio, A.T., Fernandes, S.A., Munoz, N., Rodriguez, C., Realpe, M.E., Moreno, J., Araya, P., Fernandez, J., Fernandez, A., Campos E., Duarte, F., Gustafson,
W.N., Binsztein, N. and Perez, G.E. 2012. Building PulsNet Latin America and Caribbean Salmonella regional database: first conclusions of genetic subtypes of $S$. typhi, S. typhimurium and $S$. enteritidis circulating in six countries of the region, Food Research International, 45(2):1030-1036

CARICOM, 2015. Caricom member states. http://www.caricom.org/jsp/ community/member_states.jsp?menu=community

Centres for Disease Control (CDC). 2015. Surveillance of foodborne diseases outbreaks in the United States, 2013: annual report. Atlanta, Georgia: US Department of Health and Human Services, CDC

Corning, S. 2014. World Organisation for Animal Health: strengthening veterinary services for effective One Health collaboration, scientific and technical review of the Office International des Epizooties 2014, 33 (2), 639-650

CTO (Caribbean Tourism Organization). 2015. UK \& European travel industry trends and insight report 2015. TTG Media. Available online: http://content.yudu.com/A3xojy/Caribbean-Insight-15/ resources/index.htm?referrerUrl=http $\% 3 \mathrm{~A} \% 2 \mathrm{~F} \% 2 \mathrm{Fwww}$. onecaribbean.org $\% 2 \mathrm{~F}$

de Balogh, K., Halliday, J. and Lubroth, J. 2013. Integrating the surveillance of animal health, foodborne pathogens and foodborne diseases in developing and in-transition countries. Scientific and Technical Review of the Office International des Epizooties, 32(2):539-548

Drake, M., Amadi, V., Zieger, U., Johnson, R. and Hariharan, H. 2013. Prevalence of Salmonella spp. in cane toads (Bufo marinus) from Grenada, West Indies, and their antimicrobial susceptibility, Zoonoses in Public Health, 60: 437-441

EDES c/o COLEACP (EDES-safe food in ACP-Africa, Caribbean and Pacific countries - c/o Europe-Africa-Caribbean-Pacific Liaison Committee). 2012. Food safety system. General Principals of National Surveillance. Topic 1. Handbook 1.11. Available online: http://edes.coleacp.org/files/documents/edes/publications/EDES fascicule\%201-11_EN_web.pdf

EFSA (European Food Safety Agency). 2014. Scientific report of EFSA and ECDC. The European Union summary report on trends and sources of zoonoses, zoonotic agents and food-borne outbreaks in 2012, EFSA Journal, 12(2):3547

Ehrenberg, J.P. and Ault, S.K. 2005. Neglected populations: thinking to reshape the determinants of health in Latin America and the Caribbean, BMC Public Health, 5:119

FAO (Food and Agriculture Organization of the United Nations). 2007. Sub regional report on animal genetic resources: the Caribbean. Annex to The State of the World's Animal Genetic Resources for Food and Agriculture. Rome.

FAO (Food and Agriculture Organization of the United Nations). 2014. Statistical year book 2014. Latin America and the Caribbean Food and Agriculture. Food and Agriculture Organization of the United Nations Regional Office for the Latin America and the Caribbean. Santiago do Chile.

FAOSTAT, 2015. FAO, Statistic division, Available at http://faostat3.fao. org/home/E

31.Fletcher, S.M., Lewis-Fuller, E., Williams, H., Miller, Z., Scarlett, H.P., Cooper, C., Gordon-Johnson, K.-A., Vickers, I., Shaw, K., Wellington, I., Thame, J., Pérez, E. and Indar, L. 2013. Magnitude, distribution, and estimated level of underreporting of acute gastroenteritis in Jamaica, Journal of Health, Population and Nutrition, 31(4) (Suppl):69-80

Forde, M., Morrison, K., Dewailly, E., Badrie, N. and Robertson, L. 2011. Strengthening integrated research and capacity development within the Caribbean region, BMC International Health and Human Rights, 11(Suppl 2):S7

Gabriel, O.O., Jaime, A., McKenzie, M., Auguste, A., Pérez, E. and Indar, L. 2013. Estimating the burden of acute gastrointestinal illness: a pilot study of the prevalence and underreporting in Saint Lucia, Eastern Caribbean, Journal of Health, Population and Nutrition, 31(4) (Suppl):3-16 
Gebreyes, W.A., Dupouy-Camet, J., Newport, M.J., Oliveira, C.J.B., Schlesinger, L.S., Saif, Y.M., Kariuki, S., Saif, L.J., Saville, W., Wittum, T., Hoet, A., Quessy, S., Kazwala, R., Tekola, B., Shryock, T., Biesi, M., Patchanee, P., Boonmar, S. and King, L. 2014. Opportunities for tackling infectious diseases at the human, animal, and environmental interface in low-resource settings, PLoS Neglected Tropical Diseases, 8(11): e3257

Gibbons, I.S., Adesiyun, A., Seepersdsingh, N. and Rahaman, S. 2006. Investigation for possible source(s) of contamination of ready-to-eat meat products with Listeria spp. and other pathogens in a meat processing plant in Trinidad, Food Microbiology, 23(4);359-66

Glasgow, L.M., Forde, M.S., Antoine, S.C., Pérez, E. and Indar, L. 2013. Estimating the burden of acute gastrointestinal illness in Grenada, Journal of Health, Population and Nutrition, 31(4) (Suppl):17-29

Grace, D. 2015. Food safety in low and middle income countries, International Journal of Environmental Research and Public Health, 12:10490-10507

Grace, D., Jones, B., McKeever, D., Pfeiffer, D., Mutua, F., Njuki, J., McDermott, J., Rushton, J., Said, M., Ericksen, P., Kock, R. and Alonso, S. 2011. Zoonoses: wildlife/livestock interactions. Zoonoses Project I. Report to the UK Department for International Development and ILRI. Nairobi, Kenya: ILRI, and London, UK: Royal Veterinary College

Gray, M.D., Lacher, D.W., Leonard, S.R., Abbott, J., Zhao, S., Lampel, K.A., Prothery, E., Gouali, M., Weill, F.X. and Maurelli, A.T. 2015. Prevalence of Shiga toxin-producing Shigella species isolated from French travellers returning from the Caribbean - an emerging pathogen with international implications, Clinical Microbiology and Infection, 21:765e9-775e14

Hariharan, H., Sharma, S., Chikweto, A., Matteew, V. and DeAllie, C. 2009. Antimicrobial drug resistance as determined by the E-test in Campylobacter jejuni, C. coli, and C. lari isolates from the ceca of broiler and layer chickens in Grenada, Comparative Immunology, Microbiology \& Infectious Diseases, 32(1):21-8

Hulebak, K., Rodricks, J. and DeWaal, C.S. 2013. Integration of animal health, food pathogen and foodborne disease surveillance in the Americas, Scientific and Technical Review of the Office International des Epizooties, 32(2):529-538

Indar, L. 2015. Enhancing early warning and response to travel related foodborne diseases and other public health issues occurring in stay over (hotels) and cruise ship visitors. Caribbean Public Health Agency (CARPHA) in partnership with Caribbean Tourism Organization (CTO) \& Caribbean Hotel Association (CHTA). Communication in CARPHA Regional Foodborne Diseases Surveillance and Food Safety Workshop. May 13-15, 2015, Port of Spain-Trinidad \& Tobago

Indar, L., Baccus-Taylor, G., Commissiong, E., Prabhakar, P. and Reid, H. 1998. Salmonellosis in Trinidad: evidence for transovarian transmission of Salmonella in farm eggs, West Indian Medical Journal, 47(2):50-3

Indar, L., Francis, L., Quesnel, S., Bissessarsingh, E. and Olowokure, O. 2015a. Foodborne diseases in the Caribbean, 2005-2014: changing epidemiology and implications for prevention and control. Board 178. 2015 International Conference on Emerging Infectious Diseases (ICEID). August 24-26. Atlanta, Georgia. Program and Abstracts Book, 109

Indar, L., Olowokure, B. and Pérez, E. 2015b. The burden and impact of acute gastroenteritis and foodborne diseases in the Caribbean. Board 177. 2015 International Conference on Emerging Infectious Diseases (ICEID). August 24-26. Atlanta, Georgia. Program and Abstracts Book, 109

Indar-Harrinauth, L., Daniels, N., Prabhakar, P., Brown, C., BaccusTaylor, G., Commissiong, E. and Hospedales, J. 2001. Emergence of Salmonella enteritidis phage type 4 in the Caribbean: case-control study in Trinidad and Tobago, West Indies, Clinical Infectious Diseases, 32:890-6
Kearny, J. 2010. Food consumption trends and drivers, Philosophical Transactions of the Royal Society B. 36S, 2793-2807

Kendall, M.E., Crim, S., Fullerton, K., Han, P.V., Cronquist, A.B., Shiferaw, B., Ingram, L.A., Rounds, J., Mintz, E.D. and Mahon, B.E. 2012. Travel-associated enteric infections diagnosed after return to the United States, Foodborne diseases active surveillance network (FoodNet), 2004-2009, Clinical infectious Diseases, 54: S480-S487

Khan-Mohammed, Z., Adesiyun, A.A., Swanston, W.H. and Chadee, D.D. 2005. Frequency and characteristics of selected enteropathogens in fecal and rectal specimens from childhood diarrhea in Trinidad, 1998-2000, Revista Panamericana de Salud Pública, 17(3):170-7

Kumar, A., Browne, C., Scotland, S., Krishnamurthy, K., and Nielsen, A.L. 2014. Selected enteropathogens and clinical course in children hospitalized with severe acute gastroenteritis in Barbados, International Journal of Health Sciences, Quassin University, 8(4): 410-417

Lakhan, C., Badrie, N., Ramsubhag, A., Sundaraneedi, K. and Indar, L. 2013. Burden and impact of acute gastroenteritis and foodborne pathogens in Trinidad and Tobago, Journal of Health, Population and Nutrition, 31(4) (Suppl I):30-42

Miller, R.S., Miller, W.G., Behringer, M., Hariharan, H., Matthew, V. and Oyarzabal, O.A. 2009. DNA identification and characterization of Campylobacter jejuni and Campylobacter coli isolated from caecal samples of chickens in Grenada, Journal of Applied Microbiology, 108: 1041-1049

Miller, S., Amadi, V., Stone, D., Johnson, R., Hariharan, H. and Zieger, U. 2014. Prevalence and antimicrobial susceptibility of Salmonella spp. in small Indian mongooses (Herpestes auropunctatus) in Grenada, West Indies, Comparative Immunology Microbiology and infectious Diseases, 37:205-210

Miller, S., Zieger, U., Ganser, C., Satterlee, S.A., Bankovich, B., Amadi, V., Hariharan, H., Stone, D. and Wisely, S. 2015. Influence of land use and climate on Salmonella carrier status in the small Indian mongoose (Herpestes auropunctatus) in Grenada, West Indies, Journal of Wildlife Diseases, 51(1):60-65

Mughini-Grass, L., Smid, J.H., Waagenaar, J.A., De Boer, A., Havelaar, A.H., Friesema, I.H., French, N.P., Graziani, C., Busani, L. and Van Pelt, W. 2014. Campylobacteriosis in returning travellers and potential secondary transmission of exotic strains, Epidemiology \& Infection, 142(6): 1277-88

Nastasijević, I. 2000. Integrated monitoring of zoonotic foodborne pathogens in the meat chain, Tehnologija Mesa, 50:75-80

Nkogwe, C., Raletobana, J., Stewart-Johnson, A., Suepaul, S. and Adesiyun, A. 2011. Frequency of detection of Escherichia coli, Salmonella spp., and Campylobacter spp. in the faeces of wild rats (Rattus spp.) in Trinidad and Tobago, Veterinary Medicine International, Article ID 686923, 7 pages

Paredes, P., Campbell-Forrester, S., Mathewson, J.J., Ashley, D., Thompson, S., Steffen, R., Jiang, Z.D., Svennerholm, A.M. and DuPont, H.L. 2000. Etiology of travelers' diarrhea on a Caribbean Island, Journal of Travel Medicine, 7(1):15-8

Percedo Abreu, M.I., Guitián, J., Herbert-Hackshaw, K., Pradel, J., Bournez, L., Petit-Sinturel, M., Delgado, A., Sanford, B., Trotman, M., Lazarus, C., López, J.F., Gómez, L., FrÍas-Lepoureau, M.T., Depaz, M., Phanord, S., Titus, S., Parris-Aaron, M., Gongora, V. and Lefrançois, T. 2011. Developing a disease prevention strategy in the Caribbean: the importance of assessing animal health-related risks at regional level, Scientific and Technical Review of the Office International des Epizooties, 30(3):725-73

Persuad, S., Mohamed-Rambaran, P., Wilson, A., James, C. and Indar, L. 2013. Determining the community prevalence of acute gastrointestinal illness and gaps in surveillance of acute gastroenteritis and foodborne diseases in Guyana, Journal of Health Population and Nutrition, 31(4) (suppl):57-68 
Pires, S.M., Vieira, A.R., Perez, E., Lo Fo Wong, D. and Hald, T. 2011. Attributing human foodborne illness to food sources and water in Latin America and the Caribbean using data from outbreak investigations, International Journal of Food Microbiology, 152(3):129-38

Rampersad, J., Johnson, J., Brown, G., Samlal, M. and Ammons, D. 2008. Comparison of polymerase chain reaction and bacterial culture for Salmonella detection in the Muscovy duck in Trinidad and Tobago, Revista Panamericana de Salud Pública, 23(4):264-7

Rhynd, J.R., Leighton, P.A., Elcock, D.A., Whitehall, P.J., Rycroft, A., Path, F.R.C. and Macgregor, S.K. 2014. Prevalence of Salmonella spp. and termophilic Campylobacter spp. in the small Asian mongoose (Herpestes javanicus) in Barbados, West Indies, Journal of Zoo and Wildlife Medicine, 45(4):911-914

Rist, C.L., Arriola, C.S. and Rubin, C. 2014. Prioritizing zoonoses: a proposed One Health tool for collaborative decision-making, PLoS One, 9(10):e109986

Roach, C.J., Elcock, D.A., Watson, R.C. and Douglas, K. 2003. The prevalence of Salmonella and Shigella in Chlorocebus aethiops in Barbados. Ministry of Agriculture, Veterinary Services Laboratory, [cited in 20 October 2015]; p. 1-5. URL available in: http://www. agriculture.gov.bb/agri/images/stories/information_services/ documents/2003NAC/Salmonella_and_Shigella_In_Monkeys Agriconf.pdf

Rodrigo, S., Adesiyun, A., Asgarali, Z. and Swanston, W. 2006. Occurrence of selected foodborne pathogens on poultry and poultry giblets from small retail processing operations in Trinidad, Journal of Food Protection, 69:1096-1105

Roopnarine, R.R., Ammons, D., Rampersad, J. and Adesiyun, A.A. 2007. Occurrence and characterization of verocytotoxigenic Escherichia coli (VTEC) strains from dairy farms in Trinidad, Zoonosis Public Health. 54:78-85

Soto, E., Griffin, M., Verma, A., Castillo-Alcala, F., Beierschmitt, A., Beeler-Marfisi, J., Arauz, M. and Illanes, O. 2013. An outbreak of Yersinia enterocolitica in a captive colony of African green monkeys (Chlorocebus aethiops sabaeus) in the Caribbean, Comparative Medicine. 63:439-444
Stone, D.M., Chander, Y., Bekele, A.Z., Goyal, S.M., Hariharan, H., Tiwari, K., Chikweto, A. and Sharma, R. 2014. Genotypes, antibiotic resistance, and ST- 8 genetic clone in Campylobacter isolates from sheep and goats in Grenada, Veterinary Medicine International, Article ID 212864, 8 pages

Sylvester, W.R.B., Amadi, V., Pinckney, R., Macpherson, C.N.L., Mckibben, J.S., Bruhl-Day, R., Johnson, R. and Harihanan, H. 2013. Prevalence, serovars and antimicrobial susceptibility of Salmonella spp. from wild and domestic green iguanas (Iguana iguana) in Grenada, West Indies, Zoonoses and Public Health, 61:436-441

Syne, S.-M., Ramsubhag, A. and Adesiyun, A.A. 2013. Microbiological hazard analysis of ready-to-eat meats processed at a food plant in Trinidad, West Indies, Infection Ecology and Epidemiology, 3:20450

Syne, S.-M., Ramsubhag, A. and Adesiyun A. 2015. Microbial quality of popular locally processed meats sold in retail outlets in Trinidad, West Indies. Journal of Food Protection, 78(20):333-339

Tighe, M.-K., Savage, R., Vrbova, L., Toolan, M., Whitfield, Y., Varga, C., Lee, B., Allen, V., Walton, R., Johnson, C., Dhar, B., Ahmed, R., Crowcroft, N. and Middleton, D. 2012. The epidemiology of travelrelated Salmonella enteritidis in Ontario, Canada, 2010-2011, BMC Public Health, 12:310

Vidal, S.M., Fajardo, P.I. and González, C.G. 2013. Veterinary education in the area of food safety (including animal health, food pathogens and surveillance of foodborne diseases), Scientific and Technical Review of the Office International des Epizooties. 32(2):425-431

Vokaty, S. and Torres, J.G.R. 1997. Meat from small ruminants and public health in the Caribbean, Scientific and Technical Review of the Office International des Epizooties, 16(2): 426-432

WHO (World Health Organization). 2015. WHO estimates of the global burden of foodborne diseases. Foodborne Disease Burden Epidemiology Reference Group 2007-2015. pp 255

Workman, S.N., Mathison, G.E. and Lavoie, M.C. 2005. Pet dogs and chicken meat as reservoirs of Campylobacter spp. in Barbados, Journal of Clinical Microbiology, 43(6): 2642-50 